\title{
FREQUENCY AND ANTIMICROBIAL SUSCEPTIBILITY PATTERN OF HOSPITAL ISOLATES OF ESCHERICHIA COLI AND KLEBSIELLA PNEUMONIAE IN URINE SAMPLES
}

\author{
Ivana Jukić, Danijel Topić, El-Jesah Đulić, Amela Dedeić-Ljubović
}

(C) 2019 by Acta Medica Saliniana ISSN 0350-364X

DOI: $10.5457 / 527$

Ivana Jukić

Danijel Topić

El-Jesah Đulić

Amela Dedeić-Ljubović

\section{Afiliation:}

Clinical Center University of Sarajevo, 71 ooo Sarajevo, Bosnia and Herzegovina

\section{Corresponding author:}

Amela Dedeic-Ljubovic,

E-mail: amela.ljubovic@hotmail.com

\begin{abstract}
Objectives/Aim: Urinary tract infections (UTI) are a serious public health problem and caused by many pathogens, most often by Escherichia coli and Klebsiella pneumoniae. Aim of this study was to show the frequency and antimicrobial susceptibility pattern of $E$. coli and $K$. pneumoniae in hospital isolates, following the GLASS methodology. Methods: This is a retrospective study that was conducted in the Laboratory for Urinary Infections OU Clinical Microbiology CCUS in the period from January till December 2018.

A total of 1376o urine samples were processed, using standard laboratory methods, in which significant bacteriuria was detected in $3218(23.4 \%)$ of specimens.

Results: Out of the total number of positive samples, E. coli was isolated in 1166 (36.2\%) and K. pneumoniae at 341 (10.6\%) patients. The presence of E. coli and $K$. pneumoniae isolates is dominant in females $(1103 / 73.2 \%)$ and age group 60 and older $(812 / 54.7 \%)$. Out of the total E. coli isolates, the ESBL strain was presented with 79 $(6.8 \%)$ and $K$. pneumoniae with 145 (42.5\%). The proportion of carbapenemase (CPE) produced by K. pneumoniae isolates was $8(2.4 \%)$. The ESBL strain distribution analysis on clinics showed the highest prevalence of both isolates at the Clinic for Nephrology: K. pneumoniae $26 / 17,9 \%$; E. coli: $12 / 15.4 \%$. Isolated E. coli showed the highest resistance to ampicillin 673/1166 (57,7\%), trimethoprim-sulfamethoxazole 454/1166 (38.9\%) and ciprofloxacin $253 / 970$ (26.1\%), while K. pneumoniae to ciprofloxacin and trimethoprimsulfamethoxazole with 151/285 (53.0\%) and 164/341 (48.1\%), respectively.

Conclusions: Our study has shown that the most common cause of urinary infections in hospital settings are E. coli and K. pneumoniae. Data analysis showed that the presence of ESBL isolates was significantly higher in $K$. pneumoniae than E. coli. CPE isolates of K. pneumoniae were also detected.
\end{abstract}

Keywords: urinary tract infection, Escherichia coli, Klebsiella pneumoniae, antimicrobial resistance

\section{INTRODUCTION}

Urinary tract infections (UTI) are a serious public health problem and are caused by many pathogens, most often by Escherichia coli and Klebsiella pneumoniae [1].Uncomplicated UTI usually affects women, children, and elderly patients who are otherwise healthy. Complicated UTI is usually associated with catheter use, urinary tract abnormalities, immunosuppression or previous antibiotic therapy $[2,3]$. Multiple drug-resistant uropathogens are becoming more and more problematic as members of the Enterobacteriaceae family increasingly acquire expanded spectrum $\beta$-lactamase (ESBL) and produce carbapenemase (Carbapenemaseproducing Enterobacteriaceae - CPE) [4].
In October 2015, the World Health Organization launched the Global Antimicrobial Resistance Surveillance System (GLASS) to support the global action plan on antimicrobial resistance. The aim is to support global surveillance and research to strengthen the evidence base on antimicrobial resistance (AMR) and help to inform decision-making and drive national, regional, and global actions $[5,6]$.

The aim of this study was to show the incidence of urinary infections caused by E. coli strains and K. pneumoniae, distribution of infections by gender and age, the number of $E$. coli and $K$. pneumoniae ESBL strains, the proportion of $K$. pneumoniae CPE strains, distribution of ESBL strain infections 
on clinics at CCUS and antimicrobial susceptibility patterns following the GLASS methodology.

\section{MATERIAL AND METHODS}

This is a retrospective study that was conducted in the Laboratory for Urinary Infections OU Clinical Microbiology CCUS in the period from January till December 2018.

A total of 13760 urine samples were processed, of which significant bacteriuria was detected in $3218(23.4 \%)$ of specimens. E. coli as a causative agent of UTI was isolated in $1166(36,2 \%)$ and $K$. pneumoniae in 341 (10.6\%) patients. The patients were men, women and children in different age groups.

Microbiological examination of urine samples was performed using standard laboratory methods including microscopic examination, cultivation to determine the number of bacteria and final identification with a biochemical series or automated systems such as Vitek2 ${ }^{\circledR}$ (BioMérieux, Marcy, l'Étoile, France).

Antimicrobial susceptibility testing was performed using the standardized Kirby-Bauer disk diffusion technique, in accordance with the European Committee on Antimicrobial Susceptibility Testing (EUCAST) for Antimicrobial Susceptibility Testing guidelines [7].

The following antibiotics were tested: trimethoprimsulfamethoxazole $25 \mu \mathrm{g}$ (TS), ciprofloxacin $5 \mu \mathrm{g}$ (CIP), ceftriakson $30 \mu \mathrm{g}(\mathrm{CRO})$, cefotaxime $30 \mu \mathrm{g}$ (KT), ceftazidime $10 \mu \mathrm{g}$ (CAZ), cefepim $30 \mu \mathrm{g}$ (FEP), ampicillin $10 \mu \mathrm{g}$ (AMP), imipenem $10 \mu \mathrm{g}$ (IMP), meropenem $10 \mu \mathrm{g}$ (MEM) and colistin $10 \mu \mathrm{g}$ (COL).

\section{RESULTS}

A total of 13760 urine samples were processed, of which with significant bacteriuria there were 3218 (23.4\%) samples E. coli as a causative agent of UTI was isolated in $1166(36.2 \%)$ patients, K. pneumoniae at $341(10.6 \%)$, while other pathogens were isolated in $1711(53.1 \%)$ of the patients (Figure 1 ).

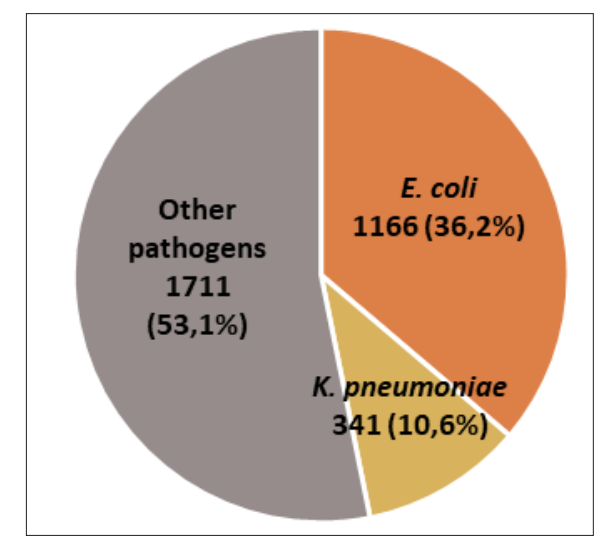

Figure 1. Incidence of urinary tract infections caused by E. coli and K. pneumoniae
Analysis of gender and age distribution showed that $E$. coli and $K$. pneumoniae isolates dominate in females with $1103(73.2 \%)$ (Figure 2) and are most often represented in the age group 60 and older with 812 (54.7\%), equally represented in the age groups of 15 45 and $45-60$ years, and the least represented in the age group 5 - 15 years with $78(5.2 \%)$ isolates (Figure 3 ).

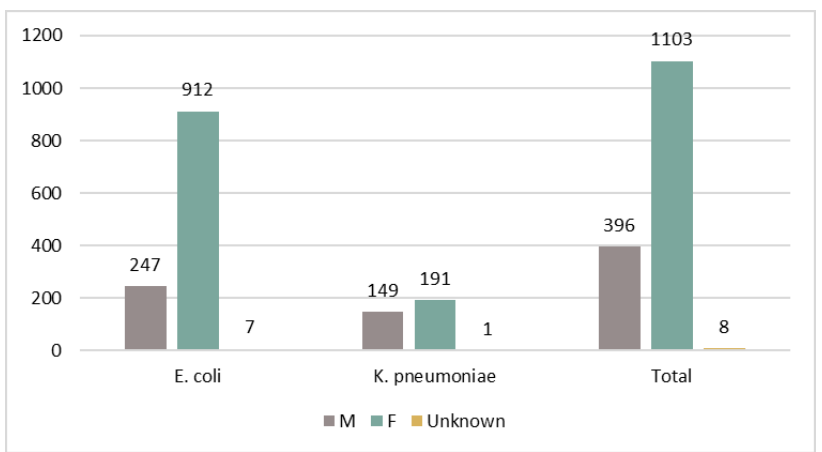

Figure 2. Incidence of urinary tract infections in relation to gender

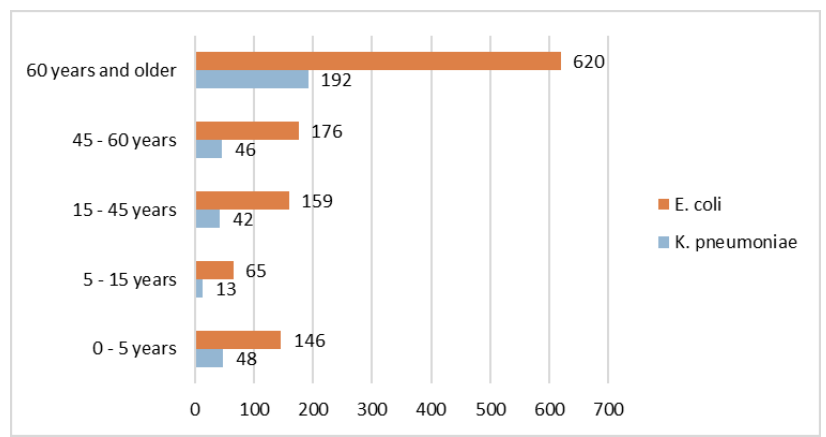

Figure 3. Incidence of urinary tract infections by age groups

Out of the total E. coli isolates, the ESBL strain was presented with 79 (6.8\%) (Figure 4) and K. pneumoniae with $145(42.5 \%)$. The proportion of carbapenemase (CPE) produced by $K$. pneumoniae isolates was 8 (2.4\%) (Figure 5).

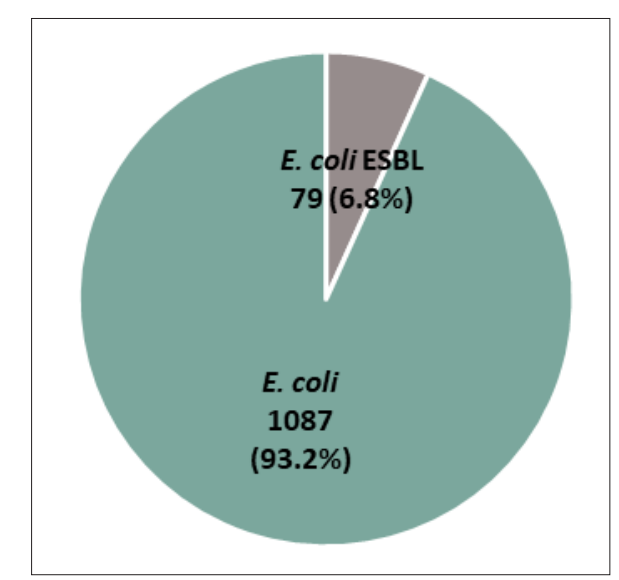

Figure 4. Distribution of E. coli ESBL isolates 


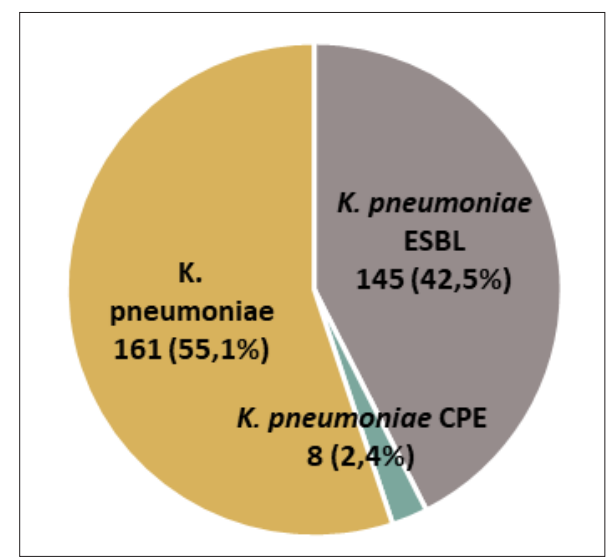

Figure 5. Distribution of K. pneumoniae ESBL isolates

The distribution of E. coli ESBL isolates in the clinics showed the highest prevalence in the Nephrology Clinic with 12 (15.2\%) isolates and the Pediatric Clinic with $10(12.7 \%)$ isolates.

Analysis of the distribution of $K$. pneumoniae ESBL isolates on clinics showed the highest prevalence in the Nephrology Clinic with 26 (17.9\%) isolates and Neurological Clinic with 22 (15.2\%) isolates (Figure 6).

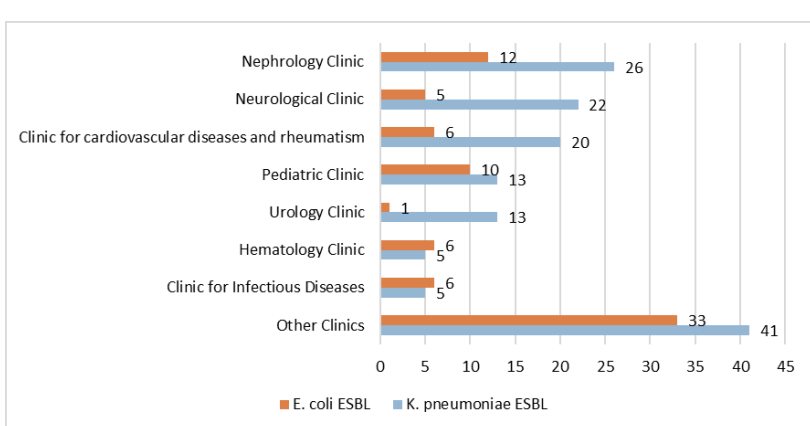

Figure 6. Distribution of E. coli ESBL and $K$. pneumoniae ESBL isolates on clinics at CCUS

Distribution of $K$. pneumoniae CPE showed that out of the 8 isolates, 2 isolates were at the Department for Pulmonary Diseases "Podhrastovi" while in other clinics they found one isolate (Department of Physical Medicine and Rehabilitation, Pediatric Clinic, Anesthesiology and Resuscitation Clinic, Neurological Clinic, Infectious Diseases Clinic and Psychiatric Clinic). Isolated E. coli showed the highest resistance to ampicillin $673 / 1166 \quad(57.7 \%)$, trimethoprimsulfamethoxazole 454/1166 (38.9\%) and ciprofloxacin $253 / 970$ (26.1\%) (Table 1), while K. pneumoniae to ciprofloxacin and trimethoprim-sulfamethoxazole with $151 / 285(53.0 \%)$ and $164 / 341$ (48.1\%) (Table 2), respectively.
Table 1. E. coli antibiotic susceptibility results tested according to the GLASS methodology.

\begin{tabular}{|c|c|c|c|c|}
\hline E. coli & & & & \\
\hline Antibiotic & $\mathrm{R}$ & $\%$ & S & $\%$ \\
\hline $\begin{array}{l}\text { Trimethoprim- } \\
\text { sulfamethoxazole (TS) }\end{array}$ & 454 & 38.9 & 712 & 61.1 \\
\hline Ciprofloxacin (CIP) & 253 & 26.1 & 717 & 73.9 \\
\hline Ceftriakson (CRO) & 83 & 7.1 & 1083 & 92.9 \\
\hline Cefotaksim (KT) & 10 & 5.1 & 186 & $94 \cdot 9$ \\
\hline Ceftazidime (CAZ) & 87 & $7 \cdot 5$ & 1079 & 92.5 \\
\hline Cefepim (FEP) & 61 & 70.1 & 26 & 29.9 \\
\hline Ampicillin (AMP) & 673 & $57 \cdot 7$ & 493 & 42.3 \\
\hline Imipenem (IMP) & o & l & 87 & 100.0 \\
\hline Meropenem (MEM) & o & / & 87 & 100.0 \\
\hline
\end{tabular}

Table 2. K. pneumoniae antibiotic susceptibility results tested according to the GLASS methodology.

\begin{tabular}{|c|c|c|c|c|}
\hline K. pneumoniae & & & & \\
\hline Antibiotic & $\mathrm{R}$ & $\%$ & S & $\%$ \\
\hline $\begin{array}{l}\text { Trimethoprim- } \\
\text { sulfamethoxazole (TS) }\end{array}$ & 164 & $48 ., \%$ & 177 & 51.9 \\
\hline Ciprofloxacin (CIP) & 151 & 53.0 & 134 & 47.0 \\
\hline Ceftriakson (CRO) & 158 & 46.3 & 183 & $53 \cdot 7$ \\
\hline Cefotaksim (KT) & 12 & 21.4 & 44 & 78.6 \\
\hline Ceftazidime (CAZ) & 159 & 46.6 & 182 & $53 \cdot 4$ \\
\hline Cefepim (FEP) & 153 & 89.5 & 18 & 10.5 \\
\hline Imipenem (IMP) & 8 & $4 \cdot 7$ & 163 & $95 \cdot 3$ \\
\hline Meropenem (MEM) & 8 & $4 \cdot 7$ & 163 & $95 \cdot 3$ \\
\hline Colistin (COL) & o & / & 8 & 100.0 \\
\hline
\end{tabular}

\section{DISCUSSION}

In this study, we evaluated the incidence and distribution of urinary infections caused by $E$. coli and K. pneumoniae, the presence of ESBL strains and their antibiotic susceptibility pattern. A retrospective study that was conducted in the Laboratory for Urinary Infections OU Clinical Microbiology CCUS in the period from January till December 2018. Out of 13760 urine samples processed, there were 3218 (23.4\%) samples with significant bacteriuria.

In our study, E. coli was the most frequent uropathogen with $36.2 \%$ of all isolates followed by $K$. pneumoniae with $10.6 \%$ while other pathogens were isolated in $53.1 \%$ patients. The similar frequency for isolates of E. coli an K. pneumoniae has been reported in studies from other countries such as Serbia (E. coli: $56.6 \%$; K. pneumoniae: $16.2 \%$ ), and France (E. coli: 41,8\%, $K$. pneumoniae: $42 \%)[8,9]$.

The presence of E. coli and $K$. pneumoniae isolates were dominant in females $(73.2 \%)$ and age group 60 and older (54.7\%) and the least represented in 
the age group 5 - 15 years with $5.2 \%$ isolates. Similar results were reported in studies conducted in France and Swiss $[9,10]$. The reasons for the high prevalence of the UTIs in females can be due to the anatomical structure of the urogenital tract having a short urethra, presence of normal flora in the vagina, menstrual cycle and pregnancy.

Out of the total E. coli isolates, the ESBL strain was presented with $6.8 \%$ and $K$. pneumoniae with $42.5 \%$. Differences in distribution between ESBL isolates of $E$. coli and $K$. pneumoniae likely reflect the different characteristics of these two bacteria. $K$. pneumoniae is a bacterium that has adapted especially to the hospital environment and survives longer than other Enterobacteriaceae on hands and environmental surfaces, making it easier to cause cross-infection within hospitals [11,12].

The prevalence of bacterial isolates expressing ESBL phenotype varies across different geographical regions with low rates of $3-8 \%$ reported in Sweden, Japan Singapore compared to much higher prevalence rates documented in studies from Portugal (34\%), Italy (37\%), New York (44\%), Latin American countries (30 - 6o\%) and Turkey (58\%) [13].

The proportion of $K$. pneumoniae CPE isolates in our hospital was $2.4 \%$. The European survey of carbapenemase-producing Enterobacteriaceae (EuSCAPE), performed in 2013-2014 in Europe, Turkey, and Israel, showed that the countries with the highest rate of carbapenem-resistant $K$. pneumoniae were Greece and Turkey, while those with the lowest were Spain and Hungary and that K. pneumoniae and E. coli produced carbapenemases, mainly KPC-type and OXA48-like [14]. Based on our results, we have much fewer CPE isolates than in Southeast European countries.

The distribution of $E$. coli ESBL isolates in the clinics showed the highest prevalence in the Nephrology Clinic with $15.2 \%$ isolates and the Pediatric Clinic with $12.7 \%$ isolates.

Analysis of the distribution of $K$. pneumoniae ESBL isolates on clinics showed the highest prevalence in the Nephrology Clinic with $17,9 \%$ isolates and Neurological Clinic with $15.2 \%$ isolates.

Isolated $E$. coli showed the highest resistance to ampicillin (57.7\%), trimethoprim-sulfamethoxazole $38,9 \%$ and ciprofloxacin (26.1\%) while the most sensitivity was to imipeneme and meropeneme $(100 \%)$. Similar results had the study conducted in 6 European Countries including Russia and study in Swiss where the resistance to ampicillin was $7,7-$ $55,8 \%$, to trimethoprim-sulfamethoxazole $7.7-41.9 \%$ and to ciprofloxacin $1.1-35,3 \%[15,10]$

In our study, $K$. pneumoniae isolates showed the highest resistance to ciprofloxacin $(53,0 \%)$ and trimethoprim-sulfamethoxazole $(48.1 \%)$, and due to a significant incidence of ESBL strains high resistance to cephalosporins (ceftriaxone and ceftazidime with 46.3\%). K. pneumoniae was most sensitive to imipenem and meropenem (95,3\%), while there was no resistance to colistin. A similar result was in South Korean study and Portugal where the resistance to ciprofloxacin was in a range from $41.3-46.5 \%$ and resistance to trimethoprim-sulfamethoxazole was 38.6 - $46.7 \%$ $[16,17]$.

Our study has shown high resistance of $E$. coli and $K$. pneumoniae to fluoroquinolones what is similar to studies conducted in many countries [16-19].

Ciprofloxacin is the most commonly prescribed fluoroquinolone for UTIs on all levels of health care [20] and the use of this antimicrobial agent as empirical therapy for UTI should be reconsidered.

Plasmids transmitting genes encoding ESBL frequently also contain genes that encode resistance to aminoglycosides, trimethoprim-sulfamethoxazole and fluoroquinolones Although there has been only one report of plasmid-mediated quinolone resistance in $K$. pneumoniae, there is a strong association between quinolone resistance and ESBL production. The reasons for this are not fully clarified [21]. It was found that $60 \%$ of the ciprofloxacin-resistant bacteria produced and ESBL compared to $16 \%$ of bacteria that were not resistant to ciprofloxacin [21].

Prevalence of antibiotic resistance in urinary tract infections caused by $E$. coli and $K$. pneumoniae is high globally, including to some first-line treatments such as trimethoprim-sulfamethoxazole, ciprofloxacin and third-generation cephalosporins.

Substantial variations in antibiotic use exist globally, with over-the-counter availability common in many countries. Primary care clinicians should consider the impact of any antibiotic use on subsequent antimicrobial resistance and avoid their unnecessary use by following local and national guidance whenever possible.

The improved infrastructure of primary care, access to healthcare, and antibiotic regulation might be necessary to reduce the burden of antimicrobial resistance.

\section{CONCLUSION}

Resistance to antibiotics is a serious health problem when developing in a bacterial species such as $E$. coli and $K$. pneumoniae.

Antibiotic consumption in many areas exceeds real needs and unjustifiably promotes resistance development, and once-produced resistant strains are easily spread in the community, especially if the genetic material encoding resistance enters the strain with a high epidemic and virulent potential. 
A better definition of epidemiologically important strains and monitoring of their reservoirs and modes of transmission would be the imperative limiting the spread of resistance and preserving the efficacy of antibiotics.

\section{SAŽETAK}

Uvod: Infekcije urinarnog trakta (IUT) su ozbiljan javno zdravstveni problem i uzrokovane su nizom patogena, a najčešće su Escherichia coli i Klebsiella pneumoniae.

Ovaj rad ima za cilj prikazati učestalost i antimikrobnu osjetljivost bolničkih izolata E. coli i K. pneumoniae, a u skladu sa metodologijom GLASS mreže.

Metode: Ovo je retrospektivna studija koja je sprovedena u laboratoriju za urinarne infekcije OJ Klinička mikrobiologija KCUS u periodu od o1.o1. do 31.12.2018. godine.

Ukupno je obrađeno 1376o uzoraka urina, standardnim laboratorijskim metodama, kod kojih je signifikantna bakteriurija dokazana u 3218 (23.4\%) uzoraka.

Rezultati: Od ukupnog broja pozitivnih uzoraka $E$. coli je izolirana kod 1166 (36.2\%), a K. pneumoniae kod 341 (10.6\%) pacijenata. Zastupljenost izolata E. coli i K. pneumoniae dominantna je u ženskom spolu (1103/73.2\%) i u dobnoj skupini 60 i više godina (812/ 54.7\%). Od ukupnog broja izolata E. coli udio ESBL sojeva je bio 79 (6.8\%), a kod $K$. pneumoniae iznosio je 145 (42.5\%). Udio izolata $K$. pneumoniae koji produkuju karbapenemaze (CPE) je iznosio 8 $(2,4 \%)$. Analiza distribucije ESBL sojeva po klinikama pokazala je najveću zastupljenost oba izolata na Klinici za nefrologiju: $K$. pneumoniae 26/17.9\%); E. coli: 12/15.4\%. Izolati $E$. coli su pokazali najveću rezistenciju na ampicilin 673/1166 (57.7\%), trimethoprimsulfamethoxazole $454 / 1166(38.9 \%)$ i ciprofloksacin 253/970 (26.1\%), dok su izolati K. pneumoniae pokazali najveću rezistenciju na ciprofloksacin i trimethoprimsulfamethoxazole 151/285 (53.0\%) i 164/341 (48.1\%).

Zaključak: Naša je studija pokazala da su najčešći uzročnici urinarnih infekcija u bolničkoj sredini $E$. coli i $K$. pneumoniae. Analiza podataka je pokazala da je zastupljenost ESBL izolata značajno veća kod $K$. pneumoniae u odnosu na E. coli. Dokazana je i pojava CPE izolata K. pneumoniae.

Ključne riječi: infekcije urinarnog trakta, Escherichia coli, Klebsiella pneumoniae, antimikrobna rezistencija

\section{REFERENCES}

1. Stamm WE, Norrby SR. Urinary tract infections: disease panorama and challenges. J Infect Diseas 2001 1; 183 (Supplement 1): S1-4.

2. Hooton TM. Uncomplicated urinary tract infection. N EnglJ Med 2012; 366(11): 1028-1037.

3. Lichtenberger P, Hooton TM. Complicated urinary tract infections. Curr Infect Dis Rep 2008; 10: 499-504.

4. Gupta K, Bhadelia N. Management of urinary tract infections from multidrug-resistant organisms. Infect Dis Clin North Am 2014; 28(1): 49-59.

5. World Health Organization. Antimicrobial resistance: global report on surveillance. World Health Organization; 2014.

6. https://www.who.int/glass/en/

7. http://www.eucast.org/ast_of_bacteria/disk_ diffusion_methodology/

8. Đorđević Z, Folić M, Janković S. Communityacquired urinary tract infections: causative agents and their resistance to antimicrobial drugs. Vojnosanitetski pregled. 2016; 73(12): 1109-1115.

9. Gravey F, Loggia G, de La Blanchardière A, Cattoir V. Bacterial epidemiology and antimicrobial resistance profiles of urinary specimens of the elderly. Medecine et maladies infectieuses. 2017; 47(4): 271-278.

10. Erb S, Frei R, Tschudin Sutter S, Egli A, Dangel M, Bonkat G, Widmer AF. Basic patient characteristics predict antimicrobial resistance in E. coli from urinary tract specimens: a retrospective cohort analysis of 5246 urine samples. Swiss medical weekly. 2018; 148(4546).

11. Casewell MW, Desai N. Survival of multiplyresistant Klebsiella aerogenes and other Gramnegative bacilli on finger-tips. J Hospital Infect 1983; 4(4): 350-36o.

12. Kramer A, Schwebke I, Kampf G. How long do nosocomial pathogens persist on inanimate surfaces? A systematic review. BMC Infect Dis 2006; 6(1): 130.

13. Al Mously N, Al Arfaj O, Al Fadhil L, Mukaddam S. Antimicrobial susceptibility patterns of ESBL Escherichia coli isolated from community and hospital-acquired urinary tract infections. J Health Specialties 2016; 4(2): 133.

14. Grundmann H, Glasner C, Albiger B, Aanensen DM, Tomlinson CT, Andrasević AT, Cantón R, CarmeliY, FriedrichAW, GiskeCG, Glupczynski Y. Occurrence of carbapenemase-producing Klebsiella pneumoniae and Escherichia coli in the European survey of carbapenemaseproducing Enterobacteriaceae (EuSCAPE): a prospective, multinational study. Lancet Infect Dis. 2017; 17(2): 153-163.

15. Ny S, Edquist P, Dumpis U, GröndahlYli-Hannuksela K, Hermes J, Kling AM, 
Klingeberg A, Kozlov R, Källman O, Lis DO, Pomorska-Wesołowska M. Antimicrobial resistance of Escherichia coli isolates from outpatient urinary tract infections in women in six European countries including Russia. J Global Antimicrob Resistance 2019; 17: 25-34.

16. Antimicrobial resistance of major clinical pathogens in South Korea Caneiras C, Lito L, Melo-Cristino J, Duarte A. Community-and Hospital-Acquired Klebsiella pneumoniae Urinary Tract Infections in Portugal: Virulence and Antibiotic Resistance. Microorganisms. 2019; 7(5): 138 .

17. Mcquiston Haslund J, Rosborg Dinesen M, Sternhagen Nielsen AB, Llor C, Bjerrum L. Different recommendations for empiric firstchoice antibiotic treatment of uncomplicated urinary tract infections in Europe. Scand J Primary Health Care 2013; 31(4): 235-240.

18. Blaettler L, Mertz D, Frei R, Elzi L, Widmer AF, Battegay M, Flückiger U. Secular trend and risk factors for antimicrobial resistance in Escherichia coli isolates in Switzerland 19972007. Infection 2009; 37(6): 534.

19. Schaeffer AJ. The expanding role of fluoroquinolones. Disease-a-Month. 2003; 49(2): 129-147.

20. Paterson DL. Recommendation for treatment of severe infections caused by Enterobacteriaceae producing extendedspectrum $\beta$-lactamases (ESBLs). Clin Microb Infection 2000; 6(9): 460-463.

21. Ibrahimagic A. Epidemiology of infections caused by Gram-negative bacteria producing extended-spectrum, plasmid-mediated AmpC beta-lactamases and carbapenemases from hospitalised and community patients (Doctoral dissertation, Prirodoslovnomatematički fakultet, Sveučilište u Osijeku).

Scan this QR code with your mobile device for instant access to the current Issue of Acta Medica Saliniana

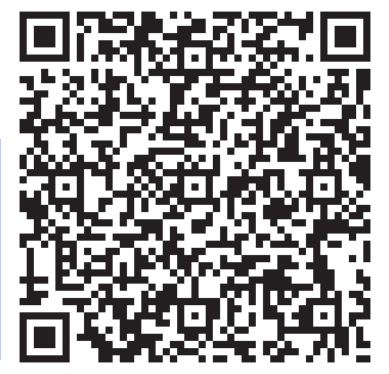

